\title{
Л.І. Янішевський
}

Житомирський обласний центр експертизи сортів рослин України

В.М. Маційчук,

кандидат сільськогосподарських наук

Житомирський національний агроекологічний університет

\section{Вплиь елементіь технологіi}

\section{buрощування на врожайність насіння сортіє льону олійного}

У статті йдеться про вплив строку сівби і норм висіву насіння сортів льону олійного на його урожайність і якість в умовах Центрального Полісся.

\section{Ключові слова:}

льон олійний, сорти льону, норми висіву льону, урожайність насіння льону, вміст олії у насінні льону.

Обґрунтування теми. Сорт $\epsilon$ біологічною основою інтенсифікації землеробства, стійкості культури проти несприятливих умов вирощування та шкідливих організмів, географічного розповсюдження [1]. Урожайність насіння льону олійного пов'язана зі ступенем зволоження й температурою грунту на час сівби; вони визначають строк сівби та норму висіву [3].

Методика досліджень. Дослідження проводилися упродовж 2007-2009 рр. Житомирським обласним державним центром експертизи сортів рослин, Черняхівський район, с. Високе. Лабораторні й польові досліди проводили за «Методикою державного сортовипробування» [2], Методичних рекомендацій по вирощуванню льону-довгунцю в умовах Житомирської обл. [3].

Трифакторний польовий дослід 3 вивчення впливу строку сівби і площі живлення на адаптивність сортів льону олійного до умов Полісся України проводився за прийнятою схемою:

Фактор А. Строки проведення сівби за температури ґрунту $5-7^{\circ} \mathrm{C}$ (перший строк) та $8-10^{\circ} \mathrm{C}$ (другий строк) на глибину загортання насіння 4-5 см, тобто за умови настання фізичної стиглості ґрунту та 50-60\% найменшої вологоємності - НB.

Фактор Б. Сорти: Айсберг контроль, Ківіка й Еврика.

Фактор В. Норма висіву за звичайного рядкового способу сівби 6 і 8 млн схожих насінин / га, 4 млн - контроль.

Площа елементарної посівної ділянки 52,7 $\mathrm{M}^{2}(2,86 \times 20 \mathrm{M})$, облікової - 50м ${ }^{2}(2,86 \times 20 \mathrm{M})$. Повторюваність досліду чотириразова. Варіанти у досліді розміщували за методом розщеплених ділянок. Фактор А строки сівби двома великими блоками. Фактори Б і В - методом розщеплених ділянок смугами у межах блоку сортів. Повторення йшли послідовно у блоках фактора А.

Технологія вирощування льону олійного, за виключенням досліджуваних елементів, була загальноприйнятою для регіону.

Результати досліджень i їx обговорення. Кращим строком сівби льону олійного $\epsilon$ ранній - за фізичної стиглості ґрунту і температури $5-7{ }^{\circ} \mathrm{C}$ на глибині загортання насіння 4-5см (табл. 1).

У цьому варіанті середня врожайність насіння становила
1,53 т/га. Запізнення із сівбою за температури $8-10^{\circ} \mathrm{C}$ на глибину 4,5 см негативно впливало на рівень врожайності насіння, втрати сягали 0,09 т/га ( IIP $_{0,5}$ строку сівби - 0,07).

Кращим 3 досліджуваних сортів льону олійного $€$ Еврика. За фізичної стиглості ґрунту (температура $5-7^{\circ} \mathrm{C}$ на глибині загортання насіння 4-5 см) цей сорт забезпечив урожайність насіння 1,59 т/га, що вище порівняно із сортами Айсберг i Ківіка відповідно на 0,10 i 0,08 т/га (HIP ${ }_{05}$ сорту 0,08). За другого строку сівби (температура ґрунту 8-10 ${ }^{\circ} \mathrm{C}$ на глибині 4-5 см) вищу врожайність насіння мав сорт Еврика - 1,52 т/га.

Незалежно від сорту оптимальною нормою висіву льону олійного $€ 6$ млн насінин / га; порівняно до контролю $4 \mathrm{Mлн}$ насінин / га прибавка врожайності в цьому варіанті становила 0,16 т/га (HIP 0 до норми висіву 0,08). За несприятливих погодних умов під час сівби або із запізненням сівби норму висіву слід збільшувати до 8 млн / га, щоб на час збирання забезпечити щільність стеблостою у межах 500 шт. / м².

Частка впливу досліджуваних факторів на приріст урожайності насіння льону олійно- 
Урожайність насіння сортів льону олійного залежно від строків сівби і норм висіву, т/га (середнє за 2007-2009 рр.)

\begin{tabular}{|c|c|c|c|c|c|c|c|c|}
\hline \multirow{2}{*}{$\begin{array}{c}\text { Температура фізично } \\
\text { стиглого ґрунту на } \\
\text { глибині 4-5 см, t С }\end{array}$} & \multirow{2}{*}{ Сорт } & \multicolumn{3}{|c|}{ Норма висіву, млн насінин. /га } & \multirow{2}{*}{$\begin{array}{c}\text { Середнє } \\
\text { сорту, т/га }\end{array}$} & \multirow{2}{*}{$\begin{array}{c} \pm \text { до } \\
\text { контролю }\end{array}$} & \multirow{2}{*}{$\begin{array}{l}\text { Середнє } \\
\text { до строку } \\
\text { сівби, т/га } \\
\end{array}$} & \multirow{2}{*}{$\begin{array}{c} \pm \text { до } 5-7 \\
{ }^{\circ} \mathrm{C}\end{array}$} \\
\hline & & 4 млн шт. & 6 млн шт. & 8 млн шт. & & & & \\
\hline \multirow{3}{*}{$5-7^{\circ} \mathrm{C}$} & Айсберг & 1,40 & 1,54 & 1,53 & 1,49 & - & 1,53 & - \\
\hline & Ківіка & 1,43 & 1,63 & 1,48 & 1,51 & 0,02 & & \\
\hline & Еврика & 1,55 & 1,68 & 1,56 & 1,59 & 0,10 & & \\
\hline \multirow{3}{*}{$8-10^{\circ} \mathrm{C}$} & Айсберг & 1,41 & 1,49 & 1,38 & 1,43 & - & 1,44 & $-0,09$ \\
\hline & Ківіка & 1,22 & 1,46 & 1,40 & 1,36 & $-0,07$ & & \\
\hline & Еврика & 1,46 & 1,59 & 1,50 & 1,52 & 0,09 & & \\
\hline $\begin{array}{c}\text { Середнє норми } \\
\text { висіву }\end{array}$ & 1,41 & 1,57 & 1,48 & & & & & \\
\hline $\begin{array}{c} \pm \text { до } 4 \text { млн насінин } \\
/ \text { га }\end{array}$ & - & 0,16 & 0,06 & & & & & \\
\hline
\end{tabular}

* HIP $_{0,5}$ строку сівби - 0,07; сорту і норми висіву - 0,08.

го від строку сівби становила $8 \%$, сорту - 15\%, норми висіву - 10\%, погодних умов року досліджень - 45\%, інших - 22\%.

Між густотою стояння рослин льону олійного за щільністю і урожайністю насіння встановлена середня від'ємна кореляційна залежність -

$$
r=-0,26 \text {. }
$$

Вплив досліджуваних факторів на рівень урожайності насіння льону олійного відбувався через зміни кількості коробочок на рослині, насінин у коробочці, масу 1000 насінин і масу насіння з рослини.

Кількість коробочок на одній рослині льону олійного коливалося від 25,9 до 35,1 шт.
Найбільша різниця за кількістю коробочок на рослині була за варіантами норм висіву. За досліджуваними сортами більше коробочок було в Еврики, потім у Ківіки й Айсберга. За строками сівби різниці були в межах похибки досліду.

Кількість насінин, що містить коробочка рослин льону олійного, коливалася від 8,7 до 9,9 шт. Найбільше їх було за першого строку сівби у сорту Айсберг - 9,0-9,9 шт., у сортів Еврика й Ківіка - 8,9-8,9 шт. По варіантах норм висіву за першого строку сівби кількість насінин у коробочці зменшувалася зі збільшенням норми висіву від 4 до 8 млн насінин / га.
Maca 1000 насінин льону олійного за варіантами досліду коливалася від 6,5 до 8,5г. Найбільші різниці за масою 1000 насінин стосувалися варіантів норм висіву. У досліджуваних сортів вагоміше насіння було у Еврики, потім у Айсберга і Ківіки. За строками сівби різниці спостерігались у межах похибки досліду.

Елементи технології вирощування льону олійного також впливали на вміст олії в насінні (табл. 2).

Найбільше впливали на вміст олії у насінні строки сівби, тому що рослини потрапляють в інші умови зволоження ґрунту і температурного режи-

Таблиця 2

Вміст олії у насінні сортів льону олійного залежно від строку сівби і норми висіву, т/га (середнє за 2007-2009 рр.)

\begin{tabular}{|c|c|c|c|c|c|c|c|c|}
\hline \multirow{2}{*}{$\begin{array}{c}\text { Температура фізично } \\
\text { стиглого ґрунту на } \\
\text { глибині 4-5 см }\end{array}$} & \multirow[b]{2}{*}{ Сорт } & \multicolumn{3}{|c|}{ Норма висіву, млн насінин / га } & \multirow{2}{*}{$\begin{array}{c}\text { Середнє } \\
\text { до сорту, } \\
\text { т/га } \\
\end{array}$} & \multirow{2}{*}{$\begin{array}{c} \pm \text { до } \\
\text { Айсберга, } \\
\text { т/га }\end{array}$} & \multirow{2}{*}{$\begin{array}{c}\text { Середнє } \\
\text { до строку } \\
\text { сівби, т/га }\end{array}$} & \multirow{2}{*}{$\begin{array}{c} \pm \text { до } 5-7 \\
{ }^{\circ} \mathrm{C}\end{array}$} \\
\hline & & 4 млн & 6 млн & 8 млн & & & & \\
\hline \multirow{3}{*}{$5-7^{\circ} \mathrm{C}$} & Айсберг & 43,1 & 42,7 & 41,9 & 42,6 & - & 44,2 & - \\
\hline & Ківіка & 47,1 & 46,9 & 45,8 & 46,6 & 4,0 & & \\
\hline & Еврика & 44,2 & 43,7 & 42,4 & 43,4 & 0,9 & & \\
\hline \multirow{3}{*}{$8-10^{\circ} \mathrm{C}$} & Айсберг & 43,3 & 42,9 & 41,8 & 42,7 & - & 44,4 & 0,2 \\
\hline & Ківіка & 47,2 & 47,0 & 46,8 & 47,0 & 4,3 & & \\
\hline & Еврика & 44,3 & 43,9 & 42,7 & 43,6 & 1,0 & & \\
\hline $\begin{array}{c}\text { Середнє норми } \\
\text { висіву } \\
\end{array}$ & 44,9 & 44,5 & 43,6 & & & & & \\
\hline $\begin{array}{c} \pm \text { до } 4 \text { млн насінин } \\
/ \text { га }\end{array}$ & - & $-0,3$ & $-1,3$ & & & & & \\
\hline
\end{tabular}

*HIP ${ }_{0,5}$ строку сівби - 0,2; сорту і норми висіву - 0,3. 
му, що призводило до зміщення періодів онтогенезу рослин, у прямій залежності від якого знаходиться величина і якість урожаю. Зміни умов температурного і водного режимів під час дозрівання насіння певним чином відбивалися на якості врожаю і, в першу чергу, на вмісті олії в насінні.

Важливим показником якості олії $\epsilon$ йодне число (г йоду у 100 г олії) і вказує на вміст в олії ненасичених жирних кислот. Зазвичай воно коливається від 175 до 200.

Серед досліджуваних елементів технології вирощування льону олійного йодне число олії істотно змінювалося під упливом біологічних особливостей сорту. Найменше йодне число було у сорту Ківіка (у межах 176180), у сорту Айсберг - 182-189 i Еврики - 188-195. Істотно підвищувалося йодне число зі збільшенням норми висіву насіння від 4 до 6 млн насінин / га і виявилось у варіантах сортів Айсберг та Еврика.

Олія льону олійного $є$ сировиною для миловарної промисловості. Здатність їі до омилення характеризується кількістю міліграмів їдкого калію, необхідного для нейтралізації як вільних, так і зв'язаних з гліцерином жирних кислот, що містяться в 1г олії. Визначено, що для більшості рослинних нерафінованих жирів число омилення коливається у межах до 5. Кислотне число лляної олії змінювалося тільки залеж-

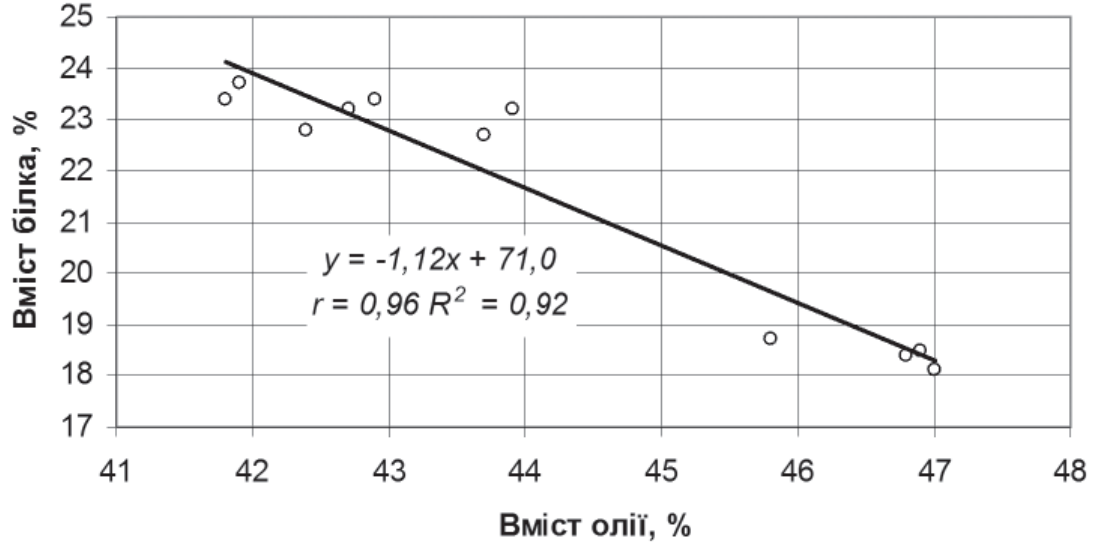

Рис. Кореляційна залежність між умістом олії й білка в насінні льону олійного (середнє за 2007-2009 рр.).

но від норми висіву. Підвищення норми висіву від 4 до 6 млн насінин / га викликало його підвищення на 0,34, за норми висіву 8 млн насінин / га підвищення було неістотним.

Між умістом у насінні олії і білка встановлена тісна зворотна залежність $-r=0,96$ (рисунок).

Кореляційна залежність діє у межах 92\% вибірки (коефіцієнт детермінації $\left.\mathrm{R}^{2}=0,92\right)$. У межах наведених показників про вміст у насінні льону олійного олії й білка, визначений за рівнянням регресії; один з них з великою вірогідністю передбачає інший.

Висновки. Кращим строком сівби льону олійного $\epsilon$ ранній за фізичної стиглості ґрунту $5-7^{\circ} \mathrm{C}$ і температури на глибині загортання насіння 4-5 cм. За цього строку середня урожайність насіння становила 1,53 т/га.

Кращим сортом льону олійного $є$ Еврика. За фізичної стиглості ґрунту i температури 5-7ㅇ на глибині загортання насіння 4-5см цей сорт забезпечував урожайність насіння 1,59 т/га, що вище порівняно із сортами Айсберг і Ківіка відповідно на 0,10 і 0,08 т/га ( HIP $_{0,5}$ до сорту 0,08$)$. За другого строку сівби (температура ґрунту 8-10 ${ }^{\circ} \mathrm{C}$, глибина - 4-5 см) вищу врожайність насіння теж мав сорт Еврика - 1,52 т/га.

Незалежно від сорту оптимальною нормою висіву льону олійного $€ 6$ млн насінин / га.

Сорти Ківіка й Еврика, порівняно до контрольного Айсберг як у перший, так і другий строки сівби мали істотно нижчий уміст білка.

За варіантами норм висіву в обидва строки сівби зі збільшенням норми висіву від 4 до 6 млн насінин / га уміст білка в насінні льону олійного мав тенденцію до збільшення.

Між умістом олії й білка в насінні льону олійного встановлена зворотна залежність $r=0,96$.

\section{ВИКОРИСТАНА ЛІТЕРАТУРА}

1. Ивашко Л.В. Новые сорта льна - залог стабильного и качественного урожая / Л.В. Ивашко, В.3. Богдан, Е.Л. Андроник, Т.М. Богдан [та інші]. Институт льна, 2000. - 24 с.

2. Методика державного сортовипробування сільськогосподарських культур. Випуск перший.
Загальна частина / за ред. В.В. Волкодава. - К., Вип. 1 - 2000. - 100 с.

3. Методичні рекомендації по вирощуванню льону-довгунцю в умовах Житомирської обл. / Ковальов В.Б., Дідора В.Г., Семченко В.І., Овсієнко О.Ф. - Житомир, 1998. - 8 с. 